\title{
Story as a Means of Engaging Public Educators and Indigenous Students
}

\author{
Martha Moon \\ Lakehead University \\ Author Note
}

I extend heartfelt thanks to the research participants who made this study possible and who made it a formative learning experience for me through the time, care, and wisdom they shared. Thank you to Paul Berger and Ruth Beatty for academic supervision and support, and to Anna Fern Kakegamic for feedback on a draft.

Funding from SSHRC, Lakehead University, and the Ontario Graduate Scholarship supported this work.

\begin{abstract}
In this study, I draw on stories and multiple perspectives as an approach presented to address two concerns in public Indigenous education: the education of teachers and the engagement of students. As a non-Indigenous educator, I conducted open-ended interviews with seven Indigenous educators and leaders in urban public school boards. The participants highlighted story as a central component for the success of Indigenous students. Participants believed that educators' understanding and teaching practices are enriched by seeking out multiple perspectives - honouring the stories of Indigenous students and their families and communities in particular. They also believed that when these stories are valued in school, students' school success increases. This paper explores several ways that story can provide modes of engagement and learning for both educators and students in public schools. These angles address the experiences that students, teachers, and families bring to schools and the stories tied to local communities and embedded in Canadian school systems. Stories are seen as intrinsically connected to the relationships and learning we share.
\end{abstract}

Keywords: story; relationship; $\mathrm{K}-12$ education; Indigenous education

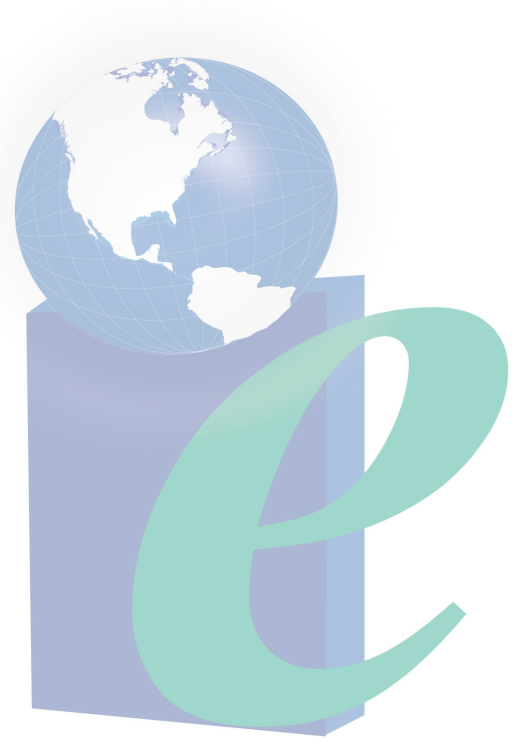




\section{Story as a Means of Engaging Public Educators and Indigenous Students}

In this article, I present story ${ }^{1}$ as an entry point to two major topics in Indigenous education: The meaning of Indigenous students' school success in public school systems and how nonIndigenous teachers might respectfully contribute to this. As a non-Indigenous educator, my interviews with Indigenous colleagues in public school boards provide the basis for this story framework. ${ }^{2}$ Since most Indigenous students attend public schools (People for Education, 2016), which tend to be staffed primarily by White teachers (Ryan, Pollock, \& Antonelli, 2007), the nexus of Indigenous education, public education, and non-Indigenous teachers' learning is of current relevance in this land we now call Canada. The premise of this article is that valuing story-Indigenous stories and perspectives in particular - can promote teachers' understanding and knowledge while at the same time creating conditions for Indigenous students' engagement and success in school.

As a EuroCanadian teacher and researcher, I did not begin this study with the intention of focusing on story. Rather, story came to the surface as I sought the insight of Indigenous colleagues on the question of what Indigenous students' success can mean in public school boards. As I read academic literature authored by Indigenous scholars, I came to see the prominence of stories and narrative ways of communicating in teaching, learning, researching, and relating (Kovach, 2009; Little Bear, 2009; Smith, 1999). These Indigenous scholars wrote about personal, relational, community, spiritual, and traditional contexts of story well beyond my experience. Wilson (2008) distinguished between types of stories and their purposes, writing that "sacred stories" are "at a higher level" involving permissions, training, and testing in order to be told by specific people (p. 98). He described "second level stories" that contain "certain morals, lessons, or events" that storytellers can shape "according to their own experience and that of the listener" (Wilson, 2008, p. 98). Finally, Wilson (2008) presented a "third style" where the teller "relate[s] personal experience or the experiences of other people" (p. 98). In the present article, the third type of story is prominent. Personal experience, and the experiences of othersincluding experiences that have taken place at a nation-to-nation level - are the main type of story described by participants.

Personal stories have been a focal point for other researchers as a mode of reciprocally connecting Indigenous students and non-Indigenous teachers. Bissell and Korteweg (2016) described the use of digital narratives as a means of communication between teachers and students through connecting on a personal level and conveying learning outcomes.

Dion's (2009) study that introduced non-Indigenous teachers to Indigenous-authored stories drew attention to potential problems when teachers take up Indigenous stories: colonial attitudes were reinforced instead of challenged. Archibald (2008) wrote about problems encountered by non-Indigenous teachers attempting to teach Indigenous stories without guidance. Sharing nuanced examples of an Indigenous and a non-Indigenous teacher, she explained how Elder storytellers "would have been helpful mentors" to teachers who could have "guided their understanding about the power of stories and helped them to learn cultural ways to make meaning from stories" (Archibald, 2008, p. 133). I am reminded that mismatches in knowledge, understanding, openness, and authority can lead to negative experiences. Engaging with stories must be done with care and proper guidance. Further, what is meant by story itself can differ across worldviews. As one example, Indigenous stories are often embedded in spirituality and connected to Elders (Archibald, 2008; Little Bear, 2009) while the current 
EuroCanadian concept of story or narrative is not necessarily spiritual (see, for example, Clandinin \& Connelly, 2000). The way stories are received and told also differs; Little Bear (2009) and Archibald (2008) described traditional processes where Elders or storytellers share stories with listeners whose responsibility it is to consider the message to draw their own conclusions. This differs from academic EuroCanadian approaches where stories are considered unfinished if not explicitly interpreted (Clandinin \& Connelly, 2000).

In Cree Narrative Memory, McLeod (2007) wrote, "Stories were offered as traces of experience through which the listeners had to make sense of their own lives and experiences" ( $p$. 13). He is writing about Cree narrative situated in kinship relationships, generations of shared history, and specific land, which is quite different from my context as an English, Irish, and Scottish Canadian from out of town. In fact, there is some irony in my drawing on this idea as McLeod (2007) discusses the "struggle to maintain nêhiyâwiwin (Cree-ness) in the face of Anglo-Canadian culture" (p. 13). At the same time, McLeod's words link to how I understand my colleagues' invitation to engage with story; an opportunity to shape my own life, teaching practices, and perspective through listening to "traces" of someone else's experience shared through story. Whether at a personal or societal level, the stories we take in shape us greatly (King, 2003).

Thus, it is with a humble and tentative stance that I approach the idea of story in public Indigenous education. I am not an expert in Indigenous storytelling nor am I a literary expert in the EuroCanadian realm. Rather, I am a teacher and researcher whose thinking and teaching practices have been shaped through interacting with Indigenous educator colleagues who have drawn my attention to the importance of story within public education. Because this research draws on the grounded theory principle that research data should form the theoretical base of the study (Savin-Baden \& Howell Major, 2013), I now turn to the words of the participants and their articulation of story's place in public education.

\section{Research Design}

This article is based on my master's thesis (Moon, 2014), ${ }^{3}$ for which I interviewed, in the spring of 2013, seven colleagues who identified as Indigenous and worked for public school boards. Participants had all been classroom teachers at some point in their careers, many with experience in more than one province, community, board, school, or position. At the time of the interviews, they held varying roles including teaching and leadership positions at school and board levels. In most cases, I shared previous professional or personal connections with participants. From my perspective, the interview tone was collegial, based on a foundation of trust and mutual acquaintance or friendship. To guide the interviews, I provided the general research question, "How would you describe success for an Aboriginal student in the public school board?" and a list of potential follow-up questions to participants in advance.

In that study, I synthesized many of the educators' insights into the "Connected Beads Model"4 (Moon, 2014; Moon \& Berger, 2016). Story was a central strand in that model and surfaced in other contexts throughout the thesis. Anecdotes or examples from each of the seven educators are included in this article. Some participants used the word story extensively while others spoke about processes and beliefs that have been drawn into this article through the framing of story as an expression of experience, a sharing of personal or group identity or history. The subsections in the findings are drawn from the interviews as a set; not every 
participant spoke about each of them. One participant in particular framed much of the interview about Indigenous students' school success around the idea of story. While I cannot name the participants due to the ethics commitments ${ }^{5}$ I made with them and with a school board, I wish to recognize here that they are the source of the conceptualization of this article.

The research was conducted in a Canadian city that is on the ancestral territory of a First Nation, and where First Nation, Métis, and Inuit people currently reside. The population of the city is ethnically diverse, the largest number of people identifying with British Isles and European origins (Statistics Canada, 2006).

As a non-Indigenous teacher and researcher, I positioned myself as a learner with respect to these colleagues; I actively sought their wisdom on the question of Indigenous student success. I invited the participants to comment on transcripts, research summaries, and a full version of the thesis. Some of them took that opportunity, and were generally affirmative or gave specific feedback that I then integrated. My analysis was inspired by some elements of a grounded theory approach (Charmaz \& Belgrave, 2012). I developed a conceptual model (Charmaz \& Belgrave, 2012) - the Connected Beads Model (Moon \& Berger, 2016) - to represent shared themes through constantly comparing all seven participants' interview responses (Savin-Baden \& Howell Major, 2013; Strauss \& Corbin, 1994).

A key aspect of my research approach was drawing on a "circle of advisors" (Moon, 2014), a group of Indigenous educators and graduate students who each agreed to help guide me as I chose a research topic, formed my interview guide, learned local protocol for seeking wisdom, and conducted interviews. Their individual support gave me perspective on my work and tangible advice at various points in the process. Thus, this research should be read within its frame of reference: the work of a non-Indigenous teacher seeking to learn about Indigenous students' school success from Indigenous colleagues.

\section{Findings and Interpretation}

Participants' views on how story can provide a conceptual framework for understanding Indigenous students' school success and an applicable practice for teachers are explored through the following sections: our own stories, the story of schooling, valuing students' stories, families and stories, community stories, story as teacher education, stories and stats, and where stories meet. Though I separate these ideas for clarity within the linear structure of this academic article, they are in fact interconnected. Students' stories are embedded in families' stories, and families' stories in communities' stories. The story of schooling (comprised of many individual stories within it), which is closely tied to the story of colonization, works its way into many of these stories as well. Educators' own stories are wound into the mix, sometimes more prominently than we acknowledge. Participants encouraged engagement with stories in teacher education and in school systems where statistics currently dominate, which in turn interacts with students', families', communities', and teachers' stories. At their best, public schools can be places where stories meet, drawing in multiple sources and forms of stories.

\section{Our Own Stories}

Several of the Indigenous educators that I interviewed emphasized that their views were situated within their own experiences. One participant said, "A lot of what I'm going to talk about is going to connect to who I am and where I come from." Later, the participant noted, "It 
doesn't mean that that's what is, but that's just the way in which I see it." This stance is also demonstrated by multiple Indigenous scholars who are clear about their own experiences and standpoints with respect to the research and writing they undertake (see Absolon \& Willett, 2005; Kovach, 2009; Smith, 2012; Wilson, 2008). The idea of being clear on our own stories was emphasized by a participant who stated that a key element for teachers seeking to contribute to Indigenous students' school success is their own understanding and awareness. One aspect of this is for teachers to acknowledge that their perspectives are one of many, and may vary from the perspective of another (Moon \& Berger, 2016). It can be difficult for EuroCanadian teachers operating in school systems that reinforce our cultural identities (Shore, 2003) to recognize that we carry cultural norms. The participants in this study reminded me that I bring my own story to education.

\section{The Story of Schooling}

While each of us brings our own experiences and perspectives, as described in the section above, we as teachers in Canadian school systems should be aware of the larger story in which we participate. As one participant noted,

What is our system founded on? The very Westernized...very White way of seeing things...and doing. So right from the get-go, there's barriers. But I find people don't want to be honest and look at those barriers. You know, and not that that's right/wrong, but... the difference for that is what creates - is what becomes almost the foundation for the inability for our students to be successful.

Thus, coming to know more about Canada's history of schooling, including underlying assumptions that Indigenous cultures and spiritual beliefs are inferior - a belief that was acknowledged in the Government of Canada's (2008) apology to the survivors of Indian Residential Schools - is foundational to understanding students' school experiences today.

This idea is fleshed out by Hampton (1995), who walked his readers through various understandings of what Indian education has meant on this continent over the past century. He said, "For most Indian students, now as in the past hundred years, Indian education means the education of Indians by non-Indians using non-Indian methods" (p. 6). Ermine (1995) outlined differences between Aboriginal and Western pursuits of knowledge, pointing out that "relentless subjugation of Aboriginal people and the discounting of their ideas" has been the effect of the "encounter of world-views" that took place at the time of Western contact with Aboriginal people (p. 101). It is crucial that I am aware that EuroCanadian educators, a group of which I am a part, have a well-established history in Indigenous education, one that has been characterized by hostility and oppression toward Indigenous cultures (Hampton, 1995). Understanding this hostility can give teachers a footing from which to cope with the problem (Hampton, 1995, $\mathrm{p}$. 37). Listening to the stories of Indigenous education in Canada, including the hard ones about people's Indian Residential School experiences, responds to survivors' hope that their stories can be shared so that the truth will be known and the public's understanding promoted (TRC, 2015).

Although schooling continues to be dominated by European views and practices (Battiste, 2013), we also live in a time when Indigenous conceptions of education are widely available for educators' engagement. Central documents such as Indian Control of Indian Education (National Indian Brotherhood/Assembly of First Nations, 1972), Royal Commission on Aboriginal Peoples (1996), and the "Holistic Lifelong Learning Models," published by the Canadian Council on 
Learning $(2007,2009)$ give great insight into the purposes and processes of education as developed by Indigenous communities and nations in this place over time. These traditions are alive today, modeled by Indigenous educators and community members. As one participant stated:

I feel like I'm doing the best teaching when kids are having fun, when they're moving, when they're breathing, when they feel honoured and important. But I do rely heavily on First Nations models in that...for example, in First Nations culture, a child is no less important than an adult, or an Elder, or a baby. Everyone-wherever you are in the cycle of life, it is honoured for what it is, and you are [a] perfect being from the time you are born. So, I really try to treat children as equals. Even though, you know, I have this job to facilitate learning...I don't act like I'm above them. At least I try not to.

This philosophy is quite different from the hierarchical model of schooling that prevails in North American public school systems (Sterling, 1995).

A participant described an Indigenous pedagogy to me, which, again, helped me to see education differently:

Typically, the way society sees success is from a Westernized pedagogy. But when you're talking about an Indigenous pedagogy, it's very different. It doesn't mean it's less expectation, it's just the expectation, actually, is bigger. It's more comprehensive. When you're looking at developing and uncovering those gifts, as I mentioned earlier, you're looking at coming to see those things that help make who you are, but those gifts that you're going to help share...traditionally, from a very young age.... when they played those games, [community members] would see who had the skills to help make - to help grow and develop, so that they may be the camp crier, or they might be the ones that would be lead warrior because of the skills they had, or they would be the one leading the hunt, so that then it was about developing those skills through those games, through those stories, so that when they became old enough, then they had nurtured those skills, so that then they could go back and help their community survive. So, it goes back to reciprocity.

Here reciprocity is a primary goal. Education holds a different purpose when competition is the underlying ideological aim (Little Bear, 2009). Having a sense of Indigenous views and traditions in education can aid teachers in considering Indigenous students' success from a more holistic standpoint.

The story of schooling is a subset of the story of Canada. Participants reminded me that current questions about Indigenous students' school success are nested within the larger history of the relationship between Indigenous people and the Crown. This can be seen as an ongoing and longstanding story. Colonization is a large part of that story (Battiste, 1998); a participant who I quoted earlier described the progression from living separately to European people coming to the land that is now called Canada. Initial "mutual trust and respect gave way to dominance," and "treaties, the Indian Act, and Residential Schools" entered the plotline of Indigenous-nonIndigenous interactions. This participant stated:

Now, we're moving more into a stage of renewal, if we look at it from an Indigenous perspective, right? Where people are coming back to our traditions, people are coming back to the language; people are coming back and being advocates, because they are 
educated but knowledgeable in our Indigenous ways. So they can walk in both-firmlyone foot in each world. We sometimes refer to that as a two-eyed way of seeing....that way of being able to see both perspectives, and to walk firmly in those two worlds.

This participant framed Indigenous students' school success within the broader story of Indigenous-Canadian relations, including oppressive realities and current trends toward change. Thus, while the schooling of Indigenous students has been forcefully assimilative on the whole (Battiste, 2013), that story is dynamic and has room for change.

\section{Valuing Students' Stories}

When asked about Indigenous students' success, one participant told me, "We have 250 students and I can give you 250 success stories." Given that each student is unique in their goals, experiences, strengths, and life circumstances, success is also unique for each. The same participant explained, "Success would just be for every student to reach and surpass their own personal potential. And that looks different for every individual person." Several participants drew my attention to the idea that each student has a unique story and a unique meaning of success. They described various modes of recognizing students' individual success. Examples they gave included the following: designing small, relational work groups where students' individual successes would be noticed, built upon, and celebrated; assemblies that celebrated personal successes; and individual learner plans that involved parents and students in setting goals and noticing their attainment. When each student is seen as a growing, developing person - a success story - education takes on new meaning.

Students' stories go beyond their school achievements. When teachers understand more about what individual students value, they become better able to support those students and to celebrate successes alongside them. Giving the examples of "doing well at the next big powwow or participating in that family's ceremony," a participant asked, "How do those feed into what's happening in that child's life in that classroom at that moment? And how are those being celebrated?" Several participants spoke about the importance of valuing and seeking out students' various stories so that their individual strengths, interests, and values can be honoured and built upon in school.

The idea that welcoming students' stories into school life can provide a means of engagement and learning for students and educators was emphasized in Bissell and Korteweg's (2016) study on the use of digital narratives to connect preservice teachers and students. Oskineegish and Berger (2013) also showed that teachers' engagement in community lifeconnecting with, learning about, and valuing what happens in students' communities outside the classroom - is a factor in successful teaching. As participants in the present study reminded me, successful practices are based in context; respectfully engaging with students' stories will differ in each setting.

An important consideration in welcoming students' stories into the classroom is that "Aboriginal perspectives and experiences [are] not about teaching our kids how to be Aboriginal. It's about providing opportunities for them to discover that for themselves. Providing opportunities for them to explore their identity, not tell[ing] them who they are!" Several participants mentioned exploring and nurturing a sense of identity, quite often in a context where exploration was a focal point. 
To close this section, I quote a participant who spoke about the "gold nugget" that can come when students feel that "somebody listened to their story...Someone honoured them in some way." Though this quotation was drawn from a larger description of a specific hypothetical context where Indigenous students' schooling could include learning experiences in a beautiful, culturally relevant physical and social environment, I believe that the underlying idea is worth drawing into other contexts. Valuing or honouring a student can mean listening to their story.

\section{Families and Stories}

Relating to students' families was integral to many participants' insight on Indigenous students' success. Two participants who were school administrators described the process of meeting with students and their families as they considered entering the school community. One participant framed this meeting around the idea of story, setting an informal tone by making tea and holding a conversation. The rationale was that it is important to "get down to the core of who they are as human beings," noting that "if you don't know who they are, then how do you even support their interests or the things that they value?" For this participant, examples of getting to know the student included conversations about where the student comes from, the languages he or she speaks, experiences at past schools, favourite teachers, and interests. The other administrator who holds meetings with families focused on collaborative and proactive discussions about students' schooling based on building accountability and trust. This participant noted that the process was time-consuming, but that it was a central feature in students' success. Taking the time to engage with one another-which could be seen as entering one another's stories - can be a stance that helps educators succeed at the work of honouring each student who enters the school and contributing positively to their learning.

Another participant highlighted the importance of being open to families' stories instead of making assumptions:

We listen to the story of the single mom who has three jobs and that's why she can't come to parent-teacher interviews. It's not because she doesn't care. Or the story of the grandmother who experienced Indian residential schools, knows that education's important, but doesn't want to go to parent-teacher interviews because she's worried about being chastised by the teacher, because that was her experience in school.

In these examples, teachers' openness to families' stories makes way for deeper understanding. This participant indicated that welcoming stories can be a respectful mode of communicating with Indigenous families, in contrast with direct questioning:

When we're working with our families, for example, instead of asking the parents, "So why isn't Billy coming to school?," we might put it in the idea of, "What can I do to help Billy come to school more often?" So you're not putting in the emphasis on that need to answer a question, but more of a need to, even, "So Billy hasn't been coming to school a lot lately," and stopping there. And giving that time for a parent to think about it, and then to respond. "Billy really likes to draw." Pause. "Yeah, he draws a lot at home." "Oh, what does he draw at home?" That leads into an opportunity for a story to happen.

Communicating through story, then, can help form connections between families and teachers. This can happen through multiple means, and can be part of a larger process of building positive relationships. 


\section{Community Stories}

Exploring stories rooted in the land where schools are situated was another approach to engaging story in public education. One participant spoke about the importance of connecting both teachers and students with community stories. An example was using place names and the names of major roads and landmarks. The participant explained how the story behind the name of a particular local road could be applied to a math lesson. The road was named after an Indigenous man famous for being able to run to a well-known location and back within a day. Students would be outside comparing the distance covered by the runner to the length of the school track. The participant followed this example by saying:

The stories that exist in this area alone. And in other areas around Canada, bring lessons to life. Students can capture those and make them their own, right? So I think giving teachers those stories, giving them the voice to use their stories. Not just our Aboriginal stories, but their own stories and their own experiences, would help aid in that development of teachers.... And that's what stories are. It's a sharing of a person.

I did not expect the connection between teaching the background of a place name and stories as "the sharing of a person." However, according to this participant, when we open ourselves up to story - our own stories, the stories of one another, and the stories written onto the land around us - we are opening ourselves up to profound possibilities in learning, in connecting with one another, and in promoting students' success.

The idea that storytelling is an opportunity for learning a new lesson through careful consideration and patience was presented by a participant who described experience working with Elders in the school board:

The Elders will tell the same story over and over again. But, as our team has realized, every time they listen to that story, they take a new lesson out of it. My Grandma used to do it to me all the time: "You told me this story already." "Well you never listened!" [laughs] "Alright, I'll listen." You might not realize why that story was being shared with you until much later on in life. Or what that means.

The traditional role of Elders as storytellers was mentioned as an important aspect of Indigenous students' success by two participants. These participants saw Elders' role in public boards as including guidance in multiple facets of school and school system life (see Moon, 2014).

Engaging with community stories in public school classrooms can include approaches like drawing upon local place names and landmarks and drawing upon Elders' guidance. In my interpretation, this assumes that school systems support teachers in developing knowledge and making connections with community members who can help guide these processes. Teachers' learning is addressed in the Truth and Reconciliation Commission (2015) Calls to Action relating to identifying "teacher-training needs" in areas like "sharing information and best practices on teaching curriculum related to residential schools and Aboriginal history" as well as "building student capacity for intercultural understanding, empathy, and mutual respect" (p. 122). This echoes the 1972 Indian Control of Indian Education emphasis on the importance of teachers' learning (NIB/AFN). In other words, the necessary shifts toward including Indigenous stories and perspectives in public schools require support for teachers. I address support in the next section where some guidance is given on educating teachers who can work toward establishing 
rich learning environments where the diverse stories and experiences of each person are listened to and valued.

\section{Story as Teacher Education}

As noted earlier, one of the participants emphasized that teachers' awareness and understanding is the first step toward Indigenous students' success: "If you're looking at success for Aboriginal students, and what are the determining factors, I think it's just having anyone understand that-how complex it is. Awareness is the first place to start." Story is one way for teachers to build their understanding.

As described above, coming to know the stories of students, their families, and the local community is one way to learn and to be responsive. More than one participant explained that since each student is unique, educators must come to know each one and respond accordingly. They were clear that this differs from responding to Indigenous students as if they are a homogenous whole. Further, it means creating school environments that honour each student and the stories they carry - both Indigenous and non-Indigenous. An important relational dynamic is established when we respond to individual students by seeing them as "our" students who "we" are responsible to get to know as people and to serve through education.

A shift toward a "we" orientation also affects how teachers are educated:

Well, a teacher education program, teacher training program? It would have to have the voice of the Elders, the voice of the community. But I think it would have to be done in a way that doesn't explicitly separate us. It's like, "Today we're going to have an Aboriginal person talk to us about Science." Instead of, "Today we're going to learn about nature, but first we're going to go for a walk, and a leader from the community is going to take us on that walk." The idea of maybe book-ending it with story and story, right? Here's a story to frame it. Here's what we're learning about today. Here's a story to end it. Even that idea of stories is a very powerful tool. But, I think it's a thing that in Western society we're losing a lot of. People are losing their stories.

What a vision for teacher education-for teachers to enter the profession with an intrinsic understanding of storytelling pedagogies and diverse community leadership! When stories become interconnected, and so do the people who hold them, rich possibilities in education begin to unfold: colleagues learning from one another, and Indigenous perspectives being valued. A participant spoke about this process, describing educators who

may not come from an Aboriginal perspective themselves... [who] get to a point that they want to learn more. They want to know more. They want to have an authentic appreciation and understanding for not only history from an Indigenous perspective here in Canada, but understanding where things are, why they are, and what can we do differently.

It was rewarding for this Indigenous educator to see certain colleagues' development: Their teaching practices shifted as they came to "understand not only in their head, but in their heart." Meaningful collegial interactions are described by St. Denis (2010) who noted the positive effects of non-Indigenous teachers who are open to learn from Indigenous colleagues and to sharing their own knowledge and support with those colleagues. Oskineegish (2015) indicated that teachers' active involvement in community shapes their understanding and teaching. 


\section{Stories and Stats}

For educators in today's school system, a very real responsibility is tracking and reporting on students' growth (see Mertler \& Campbell, 2005). Participants helped me to recognize that story is a powerful way to consider this progress. However, in a schooling culture dominated by stats, not stories, disillusionment can take hold. This has a direct effect on the quality of education for students, as described by one of the participants:

When you have some of the right-wing thinking that's out there in [a region of] Canada, and you have schools being ranked according to standardized tests and stuff, it's pretty easy for educators to get disillusioned by the fact that-okay, if this is what we're looking at, and this is what we see as success, that our school has to compete, so to speak, then there's probably a lot of educators that are thinking to themselves, "Wow, it would probably be a whole lot easier for me to work over here with these kids." In the [uppermiddle-class areas of the city].

Instead of being disillusioned by a testing-based picture of success, this participant encouraged teachers to take a different perspective-one of step-by-step growth and hope:

Sometimes it's just baby steps. You're going to do as much as you can within that school year for each of your students. They're all going to end up in different places based on where they were when they started with you. But if you can give each of them the same level of hope that they can continue to achieve success, that they can continue to do well, and they can continue to learn.... if they had teachers with that same understanding and that same feeling of self-efficacy, then I think you can lessen that gap over time. But it's not easy. And it burns a lot of teachers out.... what it comes down to is creating hope. Really. And I think that's going to look different in each setting. Based on what the needs are. So, creating hope for the students, and the teachers themselves believing that they can make a difference in what they're doing day-to-day. And if you have both of those, kids are going to be successful.

This argument for hope is rooted in seeing each student as a valuable individual, and each story as unique. As another participant explained, going back to the idea of story can be an anchor point: "We think we're making progress and then we get these numbers and we're like 'Oh.' Attendance rates. What's going on behind the attendance? What's the story behind it?" The choice to focus on story - not just statistics - as a measure of success is an intentional one. It involves not only the orientation of a classroom teacher or principal, but also a system-level stance, as another participant showed:

There're likely some really big gains and a lot of success stories that go unnoticed. Because it's much more difficult to measure those, and not only that, it's not always the biggest priority for the schools. So based on just bureaucracy and accountability and standards and the pressures, it's not always a priority.

It is clear that the definition of success needs to be reoriented in order for students' gains to be noted. This is true for individual students, and for recognizing the progress that is being made at school and system levels:

I think they need to examine the data of Aboriginal students more closely. And they need to outline not only the barriers, and where, but what's working and why.... There's been a 
lot of success, just in our own school setting. There's been a lot of success around planning for students; there's been a lot of success around successful transitioning; there's been a lot of success in building relationships with students and with families. So it all depends on what you're going to measure, again.

While participants held varying views on assessing students' progress and achievement, there was a sense of the importance of context, or story.

\section{Where Stories Meet}

In the findings shared thus far, story has been central as a form of student and teacher learning. A principle emphasized by many participants is the value of diverse learning environments where students explore multiple stories and perspectives, including their own. This could mean, for example, studying music and its origins from multiple places and times, offering school assignments where students explore their personal stories, and designing learning environments where students of all backgrounds encounter Indigenous Elders and hands-on learning opportunities. Participants showed how teachers can play a role in providing a meeting place for multiple stories. More than that, formal schooling can be a site where new shared stories emerge:

So imagine, if you would, a teacher is sharing some of their story. And then students start to share their story. And then this single story becomes two stories and three stories and four stories. And all these stories merge into another single story that creates that classroom climate - that atmosphere that those kids are able to thrive, and share, and grow. And then, those stories become experiences for those kids.

Several participants spoke about the potential that public schooling holds as a place where students encounter multiple stories and learn to interact with these in a meaningful manner that shapes their own lives.

\section{Discussion}

In the previous section, I presented and interpreted participants' insights on the meaning that story can hold at the nexus of Indigenous education, public education, and teacher learning. These findings are part of a larger study where story is one component within a model that has a strong focus on our interconnectedness as Indigenous and non-Indigenous members of school communities and Canadian society (Moon, 2014; Moon \& Berger, 2016). This interconnectedness is implied in how participants spoke about story. Teachers' coming to understand their own stories is important in relation to their students; this aids them in opening up to the perspectives represented by children who they encounter in their school lives as well as the families and communities of which those children are a part (see Moon \& Berger, 2016). The story of schooling - and the accompanying attitudes - is not distant history, but a reality that informs daily life in schools (see Hookimaw-Witt, 1998). Thus, learning about this history is a relational process when its implications and continuance are considered in light of the present. Participants discussed story in practical terms as a form of deeply engaging learning for students and teachers. Story, for students, was addressed at the identity or whole person level, giving great meaning to school-based learning experiences. For teachers, story was also presented as a form of learning, one that participants believed could affect their teaching practices and how they view success. 
I find it interesting that though the academic literature addresses difficulties that can arise for non-Indigenous teachers engaging with Indigenous stories and perspectives (Archibald, 2008; Dion 2004; 2009), few participants in this study elaborated on this. Perhaps one reason is that Indigenous students' success was the focus of the interviews; stories were shared and their importance at personal, interpersonal, and societal levels was stated and demonstrated, but story was not the centre of critique based on the research question. Further, the context in which educators spoke with me was a relational context, colleague to colleague, referring to some shared experiences and a public education setting that we both knew well. Within that public education setting, and within our own relationships, support was known to exist Berger \& Moon, 2016).This collegial support mirrors Archibald's (2008) reflections about successful instances where non-Indigenous teachers have professional development or relational support in understanding and sharing stories. In the present study, story was not an isolated approach presented for me to take away, but it was a notion that wound its way through multiple anecdotes and insights on Indigenous students' school success, a notion accompanied by the idea that strong relationships with students, families, communities, and within schools were also central to success (Moon, 2014). In this way, this small study located in an urban environment with both Indigenous and non-Indigenous educators and students could be seen to echo a principle emphasized by several Indigenous scholars: relationship and story are intrinsically connected (e.g., Archibald, 2008; Kovach, 2009; McLeod, 2007). In the present study, participants did not isolate story as a strategy to use only with Indigenous students. Story was presented as a means of engaging all people with one another. As several participants noted, the vision they shared for student success is meant for all students. It is a vision for enriching public education as a whole.

\section{Conclusion}

Through speaking with Indigenous educators in public school boards, I came to see story as a multi-faceted and deep approach to teacher learning and student engagement. Participants demonstrated the importance of recognizing one's own story and that it is one perspective of many. Welcoming students' stories and the stories of their families and communities, then, can contribute to building school environments where people feel valued and known, and where class content and activities lead to meaningful engagement within oneself and members of the school community. The broader story that frames public schooling in Canada is another story that teachers should know. Understanding our own roles within a system that has long privileged Western views and excluded Indigenous ones (Hampton, 1995) gives context to present school occurrences and relationships. At one level, story is presented here as a means of interpersonal engagement and learning with immediate applications to contributing to Indigenous students' school success. At another, teachers are invited to step into storied understandings and relationships with the purpose of building greater awareness in order to, in turn, promote students' school success. The uniting idea is that of relationship. As Indigenous and nonIndigenous members of public school communities, we are part of a much larger story of Indigenous-Canadian relations and a multitude of interconnected daily stories as we relate with one another. Relating ethically (Donald, 2012) within our intertwined stories could be our greatest opportunity.

\footnotetext{
Endnotes

${ }^{1}$ I use the singular form of the word story as a general term to describe communicating, thinking, or relating in a narrative fashion, not to imply that there is only one version of a given story or experience.
} 
${ }^{2}$ As the named author of this paper, I take responsibility for any omissions or errors.

${ }^{3}$ This article summarizes some of the findings in the author's M.Ed. thesis, Defining "Success" in Indigenous Education: Exploring the Perspectives of Indigenous Educators in a Canadian City (Moon, 2014). Early versions of these findings were presented at the American Association of Geographers' Annual meeting (April 2014), the Canadian Society for Studies in Education Conference (May 2014, June 2015, June 2016, May 2017), and a teachers' convention. Findings from the thesis are also published in the Alberta Journal of Educational Research (Moon \& Berger, 2016) and a brief synopsis was submitted to a school board handbook. Funding from SSHRC, Lakehead University, and the Ontario Graduate Scholarship supported this work.

${ }^{4}$ The Connected Beads Model is a visual representation of key findings from the study, including: a "We" approach, story, relationship, holism, and practical actions to build on these (Moon \& Berger, 2016)

${ }^{5}$ Anonymity: In keeping with ethics commitments that I made, the identities of participants and schools have been masked; gender references are made neutral, identifying features of schools are altered, and specific identities are replaced with the more general term, "Indigenous." Sadly, this means I do not give direct credit to the specific Indigenous groups whose wisdom is cited here, nor to the participants who shared their experiences. 


\section{References}

Absolon, K., \& Willett, C. (2005). Putting ourselves forward: Location in Aboriginal research. In L. Brown \& S. Strega (Eds.), Research as resistance: Critical Indigenous and antioppressive approaches (pp. 97-126). Toronto, ON: Canadian Scholars' Press.

Archibald, J. (2008). Indigenous storywork: Educating the heart, mind, body, and spirit. Vancouver, BC: University of British Columbia Press.

Battiste, M. (1998). Enabling the autumn seed: Toward a decolonized approach to Aboriginal knowledge, language, and education. Canadian Journal of Native Education 22(1), 1627.

Battiste, M. (2013). Decolonizing education: Nurturing the learning spirit. Saskatoon, SK: Purich.

Bissell, A., \& Korteweg, L. (2016). Digital narratives as a means of shifting settler-teacher horizons toward reconciliation. Canadian Journal of Education 39(3), 1-25. Retrieved from http://www.cje-rce.ca/index.php/cje-rce

Canadian Council on Learning (2007). Redefining how success is measured in First Nations, Inuit and Métis learning. Ottawa, ON. Retrieved from https://www.afn.ca/uploads/files/education/5._2007_redefining_how_success_is_measure d_en.pdf

Canadian Council on Learning (2009). The State of Aboriginal learning in Canada: A holistic approach to measuring success. Ottawa, ON. Retrieved from http://www.afn.ca/uploads/files/education2/state_of_aboriginal_learning_in_canadafinal_report\%2C_ccl\%2C_2009.pdf

Charmaz, K., \& Belgrave, L. L. (2012). Qualitative interviewing and grounded theory analysis. In J. F. Gubrium, J. A. Holstein, A. B. Marvasti, \& K. D. McKinney (Eds.), The SAGE handbook of interview research: The complexity of the craft (2nd ed., pp. 347-366). Thousand Oaks, CA: SAGE. Retrieved from http://dx.doi.org/10.4135/9781452218403

Clandinin, D. J., \& Connelly, F. M. (2000). Narrative inquiry: Experience and story in qualitative research. San Francisco, CA: Jossey-Bass.

Dion, S. D. (2004). (Re)telling to disrupt: Aboriginal people and stories of Canadian history. Journal of the Canadian Association of Curriculum Studies 2(1), 55-76. Retrieved from http://jcacs.journals.yorku.ca/index.php/jcacs/index

Dion, S. D. (2009). Braiding histories: Learning from Aboriginal peoples' experiences and perspectives. Vancouver, BC: University of British Columbia Press.

Donald, D. (2012). Forts, colonial frontier logics, and Aboriginal-Canadian relations: Imagining decolonizing educational philosophies in Canadian contexts. In A. A. Abdi (Ed.), Decolonizing philosophies of education (pp. 91-111). Rotterdam, NL: Sense.

Ermine, W. (1995), Aboriginal epistemology. In M. Battiste \& J. Barman (Eds.). First Nations education in Canada: The circle unfolds (pp. 101-112). Vancouver, BC: University of 
British Columbia Press.

Government of Canada. (2008). Indian Residential Schools statement of apology- Prime Minister Stephen Harper. Indigenous and Northern Affairs Canada. Retrieved from http://www.aadnc-aandc.gc.ca/eng/1100100015677/1100100015680

Hampton, E. (1995). Towards a redefinition of Indian education. In M. Battiste \& J. Barman (Eds.), First Nations education in Canada: The circle unfolds (pp. 5-46). Vancouver, BC: University of British Columbia Press.

Hookimaw-Witt, J. (1998). Any changes since residential school? Canadian Journal of Native Education, 22(2), 159-170. Retrieved from http://search.proquest.com/docview/230304395?pq-origsite=gscholar

King, T. (2003). The truth about stories: A Native narrative. Toronto, ON: House of Anansi Press.

Kovach, M. (2009). Indigenous methodologies: Characteristics, conversations and contexts. Toronto, ON: University of Toronto Press.

Little Bear, L. (2009). Naturalizing Indigenous knowledge, synthesis paper. Prepared for the Canadian Council on Learning's Aboriginal Learning Knowledge Centre Saskatoon, SK: University of Saskatchewan, Retrieved from https://www.afn.ca/uploads/files/education/21._2009_july_cclalkc_leroy_littlebear_naturalizing_indigenous_knowledge-report.pdf

McLeod, N. (2007). Cree narrative memory: From treaties to contemporary times. Saskatoon, SK: Purich.

Mertler, C. A., \& Campbell, C. (2005, April). Measuring teachers' knowledge \& application of classroom assessment concepts: Development of the "Assessment Literacy Inventory." Paper presented at the Annual Meeting of the American Educational Research Association, Montreal, QB. Retrieved from http://files.eric.ed.gov/fulltext/ED490355.pdf

Moon, M. (2014). Defining “success” in Indigenous education: Exploring the perspectives of Indigenous educators in a Canadian city (Master's thesis). Retrieved from Lakehead University Knowledge Commons. https://knowledgecommons.lakeheadu.ca/bitstream/2453/558/1/MoonM2014m-1b.pdf

Moon, M., \& Berger, P. (2016). Indigenous student success in public schools: A "We" approach for educators. Alberta Journal of Educational Research, 62(1), 1-18. Retrieved from ajer.journalhosting.ucalgary.ca/index.php/ajer/article/view/1431

National Indian Brotherhood/Assembly of First Nations (NIB/AFN). (1972). Indian control of Indian education: Policy paper presented to the Minister of Indian Affairs and Northern Development by the National Indian Brotherhood/Assembly of First Nations. Ottawa, ON: Author. Retrieved from http://www.oneca.com/IndianControlofIndianEducation.pdf

Oskineegish, M. (2015). Are you providing an education that is worth caring about? Advice to non-Native teachers in northern First Nations communities. Canadian Journal of 
Education, 38(3), 1-25. Retrieved from http://journals.sfu.ca/cje/index.php/cjerce/article/viewFile/1770/1770

Oskineegish. M., \& Berger, P. (2013). The role of the non-Native teacher in remote First Nations communities in northern Ontario. Canadian Journal of Native Education, 36(1), $113-$ 125. Retrieved from http://www.lights.ca/sifc/cjne.htm

People for Education (2016). Moving toward reconciliation in Ontario's publicly funded schools. Toronto, ON: People for Education. Retrieved from http://www.peopleforeducation.ca/wp-content/uploads/2016/05/P4E-IndigenousEducation-2016.pdf

Royal Commission on Aboriginal Peoples (1996). Ottawa, ON: Government of Canada. (1996). Retrieved from https://www.bac-lac.gc.ca/eng/discover/aboriginal-heritage/royalcommission-aboriginal-peoples/Pages/final-report.aspx

Ryan, J., Pollock, K., \& Antonelli, F. (2007). Teacher and administrator diversity in Canada: Leaky pipelines, bottlenecks and glass ceilings. Saskatoon, SK: Paper prepared for the Annual Conference of the Society for the Study of Education. Retrieved from http://citeseerx.ist.psu.edu/viewdoc/download?doi=10.1.1.515.1721\&rep=rep1\&type=pdf

Savin-Baden, M., \& Howell Major, C. (2013). Qualitative research: The essential guide to theory and practice. New York, NY: Routledge.

Shore, S. (2003). What's Whiteness got to do with it? Exploring assumptions about cultural difference and everyday literacy practices. Literacies, 2, 19-25. Retrieved from http://iteracies.ca/literacies/2-2003/practice/2/1.pdf

Smith, L. T. (1999). Decolonizing methodologies: Research and Indigenous peoples. London, UK: Zed Books.

Smith, L. T. (2012). Decolonizing methodologies: Research and Indigenous peoples ( $2^{\text {nd }}$ ed.). London, UK: Zed Books.

St. Denis, V. (2010). A study of Aboriginal teachers' professional knowledge and experience in Canadian schools. Saskatoon, SK: Canadian Council on Learning. Retrieved from https://www.oise.utoronto.ca/otso/UserFiles/File/ABORIGINAL_Report2010_EN_Web. pdf

Statistics Canada (2006). Population by selected ethnic origins, by census metropolitan areas (2006 Census). Retrieved from http://www.statcan.gc.ca/tables-tableaux/sumsom/z01/cs0007-eng.htm

Sterling, S. (1995). Quaslametko and Yetko: Two grandmother models for contemporary Native education pedagogy. In M. Battiste \& J. Barman (Eds.), First Nations education in Canada: The circle unfolds (pp. 113-123). Vancouver, BC: University of British Columbia Press.

Strauss, A., \& Corbin, J. (1994). Grounded theory methodology: An overview. In N. K. Denzin \& Y. S. Lincoln (Eds.) Handbook of qualitative research (pp. 273-285). Thousand Oaks, CA: SAGE. 
Truth and Reconciliation Commission of Canada (TRC). (2015). Honouring the truth, reconciling for the future: Summary of the final report of the Truth and Reconciliation Commission of Canada. Winnipeg, MB. Retrieved from http://nctr.ca/assets/reports/Final\%20Reports/Volume_6_Reconciliation_English_Web.p df

Wilson, S. (2008). Research is ceremony: Indigenous research methods. Black Point, NS: Fernwood. 